\title{
ANALISIS KOMPETENSI PEDAGOGIK GURU GEOGRAFI DI SMA SE-KECAMATAN HAMPARAN PERAK TAHUN AJARAN $2017 / 2018$
}

\author{
Rahma Yulia, Rosni \\ Jurusan Pendidikan Geografi, Fakultas IImu Sosial, Universitas Negeri Medan \\ Jl. Willem Iskandar Psr V Medan, 20221, Indonesia \\ Email: rahma.yulia@gmail.com
}

\begin{abstract}
Abstrak
Penelitian ini bertujuan untuk mengetahui Kompetensi Pedagogik Guru Geografi di SMA SeKecamatan Hamparan Perak Kabupaten Deli Serdang. Penelitian ini dilaksanakan di Kecamatan Hamparan Perak Kabupaten Deli Serdang Tahun 2017. Adapun populasi dalam penelitian ini adalah seluruh guru geografi yang mengajar di SMA Se-Kecamatan Hamparan Perak dan sekaligus menjadi sampel (total sampel) yang berjumlah 7 orang guru. Adapaun Teknik Pengumpulan Data yang digunakan untuk mengukur kompetensi pedagogik guru geografi adalah dengan menggunakan teknik observasi dan dokumentasi dengan menggunakan Instrumen Penilaian Kinerja Guru (IPKG). Teknik analisis data yang digunakan yaitu Deskritif Kualitatif. Hasil penelitian ini menunjukkan bahwa kompetensi pedagogik guru geografi dalam aspek perencanaan pembelajaran dengan menggunakan RPP termasuk dalam kategori Cukup $(79,62)$ dan dilihat dari aspek pelaksanaan pembelajaran guru geografi masih termasuk dalam kategori Kurang (64,03). Dengan demikian, hasil penelitian yang diperoleh adalah bahwa Analisis Kompetensi Pedagogik Guru Geografi di SMA SeKecamatan Hamparan Perak Tahun Ajaran 2017/2018 dapat dikategorikan dalam kemampuan Cukup (71,82).
\end{abstract}

Kata kunci: Guru, Kompetensi, Pedagogik

\section{PENDAHULUAN}

Pendidikan merupakan salah satu upaya yang dilakukan untuk membangun dan meningkatkan mutu sumberdaya manusia dalam era global yang penuh dengan tantangan dan persaingan. Pendidikan +merupakan sesuatu yang sangat fundamental bagi setiap individu dan bangsa dalam mewujudkan tujuan pembangunan. Oleh karena itu kegiatan pendidikan tidak dapat diabaikan begitu saja. Tingkat pendidikan yang baik tentu dipengaruhi oleh pendidik yang baik dan berkualitas.

Guru adalah seorang yang diposisikan sebagai garda dalam melaksanakan proses pembelajaran. Kedudukan guru tetap tidak dapat digantikan oleh media lain meskipun sekarang ini teknologi komputer berkembang dengan pesat menggantikan sebagian besar pekerjaan manusia. Dengan kata lain, guru merupakan faktor penentu keberhasilan proses pembelajaran yang berkualitas. Guru yang berkompeten akan mampu menciptakan iklim maupun lingkungan belajar yang efektif, menyenangkan, dan akan lebih mampu mengelola kelasnya, sehingga belajar para siswa berada pada tingkat optimal (Hamalik, 2009).

Menurut Mulyasa dalam Kunandar (2014) sedikitnya ada tujuh kesalahan yang sering dilakukan guru dalam pembelajaran, yaitu (1) mengambil jalan pintas dalam pembelajaran; (2) menunggu peserta didik berperilaku negatif; (3) menggunakan destructive discipline; (4) mengabaikan perbedaan peserta didik; (5) merasa paling pandai dan tahu; (6) tidak adil (diskriminaatif); (7) memaksa hak peserta didik.

Dengan demikian, dibutuhkan guru yang visioner dan mampu mengelola proses belajar mengajar secara efektif dan inovatif. Karena 
salah satu faktor utama yang menentukan mutu pendidikan adalah guru. Di tangan guru akan dihasilkan peserta didik yang berkualitas, baik secara akademis, skill (keahlian), kematangan emosional, dan moral serta spiritual. Oleh karena itu diperlukan sosok guru yang berkualitas, kompetensi, dan dedikasi yang tinggi dalam menjalankan keprofesionalannya.

Dalam Undang-undang RI No. 14 Tahun 2005, tentang Guru dan Dosen, Pasal 1 ayat 10 Guru wajib memiliki kompetensi, yakni seperangkat pengetahuan, keterampilan, dan perilaku yang harus dimiliki, dihayati dan dikuasai oleh guru dalam melaksanakan tugas keprofesionalannya. Hal ini menunjukkan bahwa kompetensi yang harus dimiliki oleh guru dalam melaksanakan tugasnya adalah kompetensi yang utuh dan integratif. Dalam proses belajar mengajar, seorang guru mempunyai tugas untuk mendorong, membimbing dan memberikan fasilitas belajar bagi siswa untuk mencapai tujuan. Guru mempunyai tanggungjawab untuk melihat segala sesuatu yang terjadi dalam kelas dan untuk membantu proses perkembangan siswa. Untuk itu seorang guru perlu memiliki kepribadian, menguasai bahan pelajaran dan mengasai cara-cara mengajar sebagai kompetensinya. Tanpa hal tersebut guru akan gagal dalam melaksanakan tugasnya. Karena kompetensi mengajar harus dimiliki oleh seorang guru yang merupakan kecakapan atau keterampilan dalam mengelola kegiatan pendidikan.

Berdasarkan pengamatan tentang realita kompetensi guru saat ini masih beragam. Sejalan dengan tantangan kehidupan global, peran dan tanggung jawab guru pada masa mendatang akan semakin kompleks, sehingga menuntut guru untuk senantiasa melakukan berbagai peningkatan dan penyesuaian penguasaan kompetensinya. Guru harus lebih dinamis dan kreatif dalam mengembangkan proses pembelajaran siswa. Guru di masa mendatang tidak lagi menjadi satu-satunya pemberi informasi terbaik terhadap barbagai informasi dan pengetahuan yang sedang berkembang dan berinteraksi dengan manusia serta guru bukan satu-satunya orang yang lebih pandai di tengah-tengah siswanya. Jika guru tidak memahami mekanisme dan pola penyebaran informasi yang demikian cepat, maka akan terpuruk secara profesional yang berakibat hilangnya kepercayaan baik dari siswa, orang tua maupun masyarakat. Untuk menghadapi tantangan profesionalitas tersebut, guru harus melakukan pembaruan ilmu dan pengetahuan yang dimilikinya secara terus menerus karena proses pembelajaran dan hasil belajar para siswa bukan hanya ditentukan oleh sekolah, pola, struktur, dan kurikulumnya, akan tetapi sebagian besar ditentukan oleh kompetensi yang dimiliki seorang guru itu sendiri. Guru yang berkompeten akan menciptakan lingkungan belajar yang efektif, menyenangkan dan mampu mengelola kelasnya.

Kompetensi yang wajib dikuasai oleh guru minimal meliputi kompetensi pedagogik, kompetensi kepribadian, kompetensi sosial, dan kompetensi profesional yang diperoleh melalui pendidikan profesi. Dalam pelaksanaan tugas guru sebagai pendidik, kompetensi guru tersebut harus saling mendukung satu sama lain. Meskipun guru harus memiliki standar yang diharapkan melalui empat kompetensi tersebut, namun dalam melaksanakan tugasnya, guru harus benar-benar memahami kompetensi mana saja yang harus ditunjukkan secara nyata untuk mendukung perannya sebagai seorang guru sehingga dapat menunjukkan bahwa dia adalah guru yang profesional.

Menurut Permendibud No. 16 Tahun 2007 kompetensi pedagogik yang harus dimiliki guru adalah: (1) Menguasai karakteristik peserta didik dari aspek fisik, moral, spiritual, sosial, kultural, sosialemosional. (2) Menguasai teori belajar dan prinsip-prinsip pembelajaran yang mendidik. (3) Mengembangkan kurikulum yang terkait dengnan mata pelajaran geografi. (4) Menyelenggarakan pembelajaran yang mendidik. (5) memanfaatkan teknologi informasi dan komunikasi dalam pembelajaran geografi. (6) Memfasilitasi pengembangan potensi yang dimiliki. (7) Berkomunikasi secara efektif, empatik dan santun dengan peserta didik. (8) menyelenggarakan penilaian dan evaluasi proses dan hasil belajar. (9). Memanfaatkan hasil penilaian dan evaluasi untuk kepenntingan pembelajaran. (10) Melakukan tindakan refleksi untuk peningkatan kualitas pembelajaran (Irwantoro, dkk, 2016)

Berdasarkan hasil observasi yang dilakukan di beberapa sekolah SMA di kecamatan 
Hamparan Perak, pelaksanaan pembelajaran geografi belum terlaksana dengan yang diharapkan. Hal ini dikarenakan guru yang mengajar pelajaran geografi bukan merupakan lulusan sarjana geografi. Hal ini dapat mempengaruhi proses pembelajaran geografi didalam kelas karena guru tidak berkompeten di bidang geografi. Beberapa guru yang mengajar pelajaran geografi tidak merancang perangkat pembelajaran (RPP) dan menyesuaikannya dengan karakteriristik peserta didik, akan tetapi guru tersebut hanya mengambil RPP dari internet. Selain itu guru juga tidak membawa RPP saat pembelajaran berlangsung. Metode yang digunakan oleh guru juga menggunakan metode ceramah (convensional) sehingga banyak siswa yang tidak tertarik dan semangat untuk mengikuti pembelajaran yang dibawakan oleh guru. Media pembelajaran seperti proyektor, bukubuku, alat peraga dan jaringan internet sebagai penunjang pelaksanaan pembelajaran yang disediakan oleh pihak sekolah juga masih minim. Selain itu, masih terdapat guru-guru yang tidak melakukan refleksi guna meningkatkan kualitas pembelajaran didalam kelas.

Guru juga menyatakan bahwa terdapat masalah lain dalam pelaksanaan pembelajaran geografi, diantaranya yaitu siswa kurang berminat dan agresif dalam pelajaan geografi. Hal ini dibuktikan dengan rendahnya nilai geografi yang diperoleh siswa. Guru mengalami kesulitan pada sebagian materi pelajaran geografi seperti konsep geografi, SIC, perhitungan penduduk, pemetaan dan lapisan tanah. Selain itu guru juga jarang mengikuti pelatihan-pelatihan/workshop guna menambah dan memperbaharui mengetahuan guru tersebut.

Berdasarkan fakta yang ditemukan di sekolah SMA di Kecamatan Hamparan Perak, maka perlu dikaji penelitian tentang Analisis Kompetensi Pedagogik Guru Geografi di SMA Se-Kecamatan Hamparan Perak Tahun Ajaran 2017/2018.

\section{METODE PENELITIAN}

Penelitian ini berlokasi di SMA Negeri 1 Hamparan Perak, SMA Swasta Pelita Bulu
Cina, SMA Swasta Swadaya Bulu Cina, SMA Swasta Melati Hamparan Perak, SMA Swasta Al-Fattah, SMA Swasta PAB 5 Klumpang, dan SMA Swasta BPI Paluh Kurau.

Pemilihan lokasi tersebut dikarenakan terdapat permasalahan mengenai kompetensi pedagogik guru yang berkaitan dengan perencanaan pembelajaran dan pelaksanaan pembelajaran dan sepengetahuan penulis belum pernah dilakukan penelitian dengan permasalahan yang sama di sekolah tersebut. Populasi dan sampel dalam penelitian ini adalah seluruh guru geografi di SMA SeKecamatan Hamparan Perak yang berjumlah 7 orang guru.

Teknik pengumpulan data dalam penelitian ini yaitu:

1. Observasi

Observasi merupakan pengamatan langsung yang dilakukan oleh peneliti kepada objek yang diteliti. Dalam hal ini peneliti mengamati secara langsung kegiatan pembelajaran yang dilakukan oleh guru geografi. Penilaian kompetensi guru dalam pelaksanaan pembelajarn yang dilakukan di dalam kelas adalah dengan menggunakan IPKG II.

2. Dokumentasi

Studi dokumentasi dilakukan untuk memperoleh data-data yang terdokumentasi pada instansi terkait pelaksanaan pembelajaran dengan mengambil foto dan video guru geografi saat pembelajaran berlangsung, RPP, data fisik dan sosial sekolah. Penilaian kompetensi guru dalam perencanaan pembelajaran dilakukan dengan menggunakan IPKC I.

Teknik analisis data yang digunakan dalam penelitian ini adalah deskriptif kualitatif yaitu mentabulasikan data yang dikumpulkan kemudian menguaraikan dan menganalisis data berdasarkan persentase dan tabel frekuensi sehingga lebih mudah untuk dipahami dan disimpulkan.

Untuk menganalisis data, maka peneliti dan Evaluator yang ditugaskan akan melakukan penskoran/pemberian nilai sesuai dengan jenis tugas/indikator yang ada pada lembar penilaian IPKC I dan IPKC II dengan kriteria penilaian pada tabel 1 . 
Tabel 1. Skor Penilaian Lembar IPKC

\begin{tabular}{ccc}
\hline No & Kriteria & Skor \\
\hline 1 & Sangat Baik & 4 \\
2 & Baik & 3 \\
3 & Cukup & 2 \\
4 & Kurang & 1 \\
\hline
\end{tabular}

Untuk menganalisis data-data hasil observasi yang telah dilakukan sesuai dengan Lembar IPKG I dan IPKC II maka digunakan persamaan:

Nilai Rata-rata $=$ Jumlah Skor/Skor Maksimum $\times 100$
Jika dalam persentase, skor Rata-rata

$=$ Skor yang diperoleh / Skor Maksimum $x$ $100 \%$

Dengan Kriteria Penilaian Sebagai berikut:

Tabel 2. Kriteria Penilaian

\begin{tabular}{ccc}
\hline No & Kriteria & Persen \\
\hline 1 & Sangat Baik & $90-100 \%$ \\
2 & Baik & $80-89 \%$ \\
3 & Cukup & $70-79 \%$ \\
4 & Kurang & $<70 \%$ \\
\hline & & Sumber: Arikunto (2013)
\end{tabular}

\section{HASIL DAN PEMBAHASAN}

\section{Kualifikasi Akademik}

Tingkat pendidikan dapat
menentukan kemampuan guru dalam mengajar serta menunjukkan profesionalisme guru. Tingkat pendidikan guru geografi dalam penelitian ini dapat dilihat pada tabel berikut.

Tabel 3. Kualifikasi Akademik Guru Geografi di SMA Se-Kecamatan Hamparan Perak Tahun Ajaran $2017 / 2018$.

\begin{tabular}{ccccc}
\hline No & Kualifikasi & Jurusan & $\begin{array}{c}\text { Jumlah } \\
\text { (orang) }\end{array}$ & Persentase (\%) \\
\hline 1 & S-1 & Pendidikan Geografi & 4 & 57,1 \\
2 & S-1 & Pendidikan Bahasa Inggris & 1 & 14,3 \\
3 & S-1 & Hukum Islam & 1 & 14,3 \\
4 & SMEA & - & 1 & 14,3 \\
\hline & Jumlah & 4 & 7 & 100 \\
\hline
\end{tabular}

Berdasarkan tabel 3 dapat dilihat bahwa tidak semua guru geografi di SMA SeKecamatan Hamparan Perak memiliki kualifikasi akademik sarjana dan berlatar belakang dari pendidikan geografi, terdapat $57,1 \%$ guru geografi sesuai dengan latar belakang pendidikan dan $42,9 \%$ guru tidak sesuai dengan latar belakang pendidikan.

\section{Pengalaman Mengajar}

Pengalaman mengajar merupakan hal yang sangat penting bagi seorang guru. Semakin lama pengalaman mengajar seseorang maka kemampuan mengajar yang dimiliki akan semakin baik. Pengalaman mengajar guru geografi di SMA Se-Kecamatan Hamparan Perak dapat dilihat pada tabel 4. 
Tabel 4. Lama Guru Mengajar di SMA Se-Kecamatan Hamparan Perak Tahun Ajaran 2017/2018

\begin{tabular}{cccc}
\hline No & Lama Mengajar (Tahun) & Jumlah & Persentase (\%) \\
\hline 1 & $0-10$ & 2 & 28,6 \\
2 & $11-20$ & 2 & 28,6 \\
3 & $21-30$ & 1 & 14,2 \\
4 & $31-40$ & 2 & 28,6 \\
\hline & Jumlah & 7 & 100 \\
\hline
\end{tabular}

Sumber: Data Primer, 2017

Tabel 4 menjelaskan bahwa lama guru mengajar paling lama 31-40 tahun sebanyak $28,6 \%, \quad 21-30$ sebanyak $14,2 \%, \quad 11-20 \%$ sebanyak $28,6 \%$ dan lama mengajar paling rendah 0-10 tahun sebanyak $28,6 \%$.

\section{Kompetensi Pedagogik}

Kompetensi pedagogik berdasarkan aspek Rencana Pelaksanaan Pembelajaran (RPP) dapat dilihat dari hasil data observasi dan dokumentasi yang dilakukan di SMA SeKecamatan Hamparan Perak. Dalam menyusun Rencana Pelaksanaan Pembelajaran (RPP) guru geografi mendapatkan nilai rata-rata 79,62 . Untuk penjelasannya dapat dilihat di tabel 5 berikut.

Tabel 5. Penilaian Kompetensi Pedagogik Guru Geografi Berdasarkan Aspek Perencanaan Pelaksanaan Pembelajaran (RPP) di SMA Se-Kecamatan Hamparan Perak Tahun Ajaran 2017/2018

\begin{tabular}{|c|c|c|c|c|c|c|}
\hline \multirow{2}{*}{ No } & \multirow{2}{*}{ Nama Guru } & \multicolumn{3}{|c|}{ Penilaian } & \multirow{2}{*}{ Rata-rata } & \multirow{2}{*}{ Kategori } \\
\hline & & RPP 1 & RPP 2 & RPP 3 & & \\
\hline 1 & Guru 1 & 93,33 & 97,5 & 98,33 & 96,33 & Sangat Baik \\
\hline 2 & Guru 2 & 83,33 & 86,66 & 84,16 & 84,71 & Baik \\
\hline 3 & Guru 3 & 61,66 & 56,66 & 60 & 59,44 & Kurang \\
\hline 4 & Guru 4 & 75,83 & 79,16 & 69,16 & 74,71 & Cukup \\
\hline 5 & Guru 5 & 86,66 & 95 & 85,83 & 89,16 & Baik \\
\hline 6 & Guru 6 & 75,83 & 75 & 79,16 & 76,66 & Cukup \\
\hline 7 & Guru 7 & 74,16 & 76,66 & 78,33 & 76,33 & Cukup \\
\hline \multirow{2}{*}{\multicolumn{2}{|c|}{$\begin{array}{c}\text { Total Skor } \\
\text { Rata-rata }\end{array}$}} & 550,8 & 566,64 & 557,39 & 557,34 & \multirow{2}{*}{ Cukup } \\
\hline & & 78,68 & 80,94 & 79,28 & 79,62 & \\
\hline
\end{tabular}

Berdasarkan tabel 5 dapat dilihat bahwa kemampuan guru geografi SMA Se-Kecamatan Hamparan Perak dalam aspek perencanaan pembelajaran mendapatkan nilai rata-rata 79,62 dengan kategori Cukup. Nilai Rencana Pelaksanaan Pembelajaran (RPP) yang paling tinggi diperoleh guru geografi SMA Negeri 1 Hamparan Perak yaitu 96,33 dengan kategori Sangat Baik dan nilai Rencana Pelaksanaan Pembelajaran Paling rendah diperoleh guru geografi SMA Swasta Swadaya yaitu 59,44 dengan kategori Kurang.

Pelaksanaan penilaian Rencana Pelaksanaan Pembelajran (RPP) juga dapat diketahui dengan skor yang diperoleh guru menurut aspek penilaian perencanaan pembelajaran yang dapat dilihat pada tabel 6 berikut.

Tabel 6. Penilaian Rata-Rata RPP Menurut Komponen Penilaian di SMA Se-Kecamatan Hamparan Perak Tahun Ajaran 2017/2018

\begin{tabular}{ccccccccccc}
\hline \multirow{2}{*}{ No } & \multirow{2}{*}{ Nama Guru } & \multicolumn{1}{c}{ Komponen Penilaian } \\
\cline { 3 - 11 } & G & B & C & D & E & F & G & H & I \\
\hline 1 & Guru 1 & 4 & 4 & 4 & 3.73 & 3,83 & 3,91 & 3,6 & 4 & 4 \\
2 & Guru 2 & 4 & 3,33 & 3,83 & 3,6 & 3,75 & 3,83 & 3,30 & 3,73 & 2,08 \\
3 & Guru 3 & 4 & 3,2 & 2,66 & 3,31 & 2,86 & 1,6 & 1,99 & 2,93 & 1,75 \\
4 & Guru 4 & 4 & 2,83 & 3.33 & 2,86 & 3,03 & 3,03 & 2,99 & 3,6 & 2,33 \\
5 & Guru 5 & 4 & 3,66 & 3,83 & 3,6 & 3,51 & 3,33 & 3,55 & 3,86 & 3,08 \\
6 & Guru 6 & 4 & 3,36 & 3 & 3,6 & 3,41 & 3,45 & 2,99 & 3,53 & 1,5 \\
7 & Guru 7 & 4 & 3,41 & 3 & 3,6 & 3,4 & 2,66 & 3,19 & 3,53 & 1 \\
\hline & Jumlah & 28 & 23,78 & 23,65 & 24,3 & 23,79 & 21,81 & 21,61 & 25,18 & 15,74 \\
\hline & Rata-rata & 4 & 3,39 & 3,37 & 3,47 & 3,39 & 3,11 & 3,08 & 3,59 & 2,24 \\
\hline
\end{tabular}

Sumber: Data Primer Olahan, 2017 
Keterangan:

A: Identitas Mata Pelajaran

B: Perumusan Indikator

C: Perumusan Tujuan Pembelajaran

D: Pemilihan Materi Ajar

E: Pemilihan Sumber Belajar

Tabel 7 menunjukkan bahwa skor ratarata Rencana Pelaksanaan Pembelajaran (RPP) menurut komponen penilaian berkisar antara 0,00-4,00. Komponen yang mendapatkan nilai 4 adalah identitas mata pelajaran. Pada komponen ini semua guru geografi telah merancangnya dengan baik hal ini dikarenakan pada komponen identitas mata pelajaran guru hanya perlun mencantumkan nama sekolah, mata pelajaran, kelas/semester, materi pokok dan alokasi waktu.

Pada komponen perumusan indikator nilai rata-rata yang diperoleh guru geografi masuk dalam kategori baik dengan perolehan nilai 3,39. Akan tetapi masih terdapat guru geografi yang belum merumuskan indikator sesuai dengan SKL, KI, KD dan kurang sesuai dengan pengetahuan, keterampilan serta penggunaan kata kerja operasional yang dapat mengukur kompetensi yang akan dicapai. Sedangkan pada komponen perumusan tujuan pembelajaran nilai rata-rata yang diperoleh guru geografi masuk dalam katergori baik dengan perolehan nilai 3,37. Dimana rata-rata guru mampu merumuskan tujuan pembelajaran sesuai dengan indikator dan sesuai dengan perumusan dalam aspek Audience, Behavior, condition dan Degree (ABCD).

Pada komponen pemilihan materi ajar nilai rata-rata yang diperoleh guru geografi masuk dalam kategori baik dengan perolehan nilai 3,47. Hal ini dikarenakan guru geografi mampu merancang materi pelajaran yang sesuai dengan tujuan pembelajaran, sesuai dengan karakteristik peserta didik dan keruntutan materi ajar yng akan disampaikan. Pada komponen pemilihan sumber belajar nilai rata-rata yang diperoleh guru geografi masuk dalam kategori baik dengan perolehan nilai 3,39. Dimana guru tidak hanya menggunakan buku pedoman geografi saja sebagai sumber belajar akan tetapi menggunakan buku refrensi lain yang relevan, dari perpustakaan, jurna dan internet. Pada pemilihan media ajar nilai rata-rata yang

\author{
F: Pemilihan Media Ajar \\ G: Metode Pembelajaran \\ $\mathrm{H}$ : Skenario Pembelajaran \\ I: Rancangan Penilaian Authentic
}

diperoleh guru geografi masuk dalam kategori baik dengan perolehan nilai 3,11. Sebagian guru sudah menggunakan media pembelajaran yang sesuai dengan tujuan pembelajaran, materi pembelajaran, sesuai dengan pendekatan scientific dan sesuai dengan karakteristik peserta didik. Dimana guru menggunakan media proyektor untuk menampilkan materi pembelajaran, menayangkan video pembelajaran dan menggunakan peta dalam menyampaikan materi pembelajaran.

Selanjutnya pada komponen metode pembelajaran nilai rata-rata yang diperoleh guru geografi masuk dalam kategori baik dengan perolehan nilai 3,08. Dimana sebagian guru sudah menggunakan metode pembelajaran yang sesuai dengan tujuan pembelajaran, sesuai dengan pendekatan scientific dan sesuai dengan karakteristik peserta didik. Metode yang digunakan oleh guru geografi dalam pembelajaran yaitu diskusi, pemecahan masalah, inquiri, tanya jawab, presentasi dan penugasan. Sedangkan pada komponen skenario pembelajaran nilai rata-rata yang diperoleh guru geografi masuk dalam kategori baik dengan perolehan nilai 3,59. Dimana sebagian guru sudah menampilkan kegiatan pendahuluan, kegiatan inti dan kegiatan penutup. Selain itu kegiatan pembelajaran sesuai dengan pendekatan scientific (mengamati, menanya, mengumpulkan data, mengasosiasi, menyimpulkan) dan sesuai dengan metode pembelajaran yang digunakan. Dan dalam rancangan penilaian authentic nilai rata-rata yang diperoleh guru geografi masuk dalam kategori cukup dengan perolehan nilai 2,24. Dimana sebagian guru belum merancang penilaian sesuai dengan indikator pencapaian kompetensi dan belum sesuai dengan teknik, bentuk dan instrumen penilaian sikap.

Selanjutnya analisis kompetensi pedagogik guru geografi dilihat dari aspek perencanaan pembelajaran dapat dikategorikan dalam tabel 8. 
Tabel 8. Kategori Penilaian Kompetensi Pedagogik Guru Geografi Berdasarkan Aspek Perencanaan Pembelajaran (IPKG I)

\begin{tabular}{ccccc}
\hline No & Rentang Nilai & Jumlah Guru & Persen $(\%)$ & Kategori RPP \\
\hline 1 & $90-100$ & 1 & 14,3 & Sangat Baik \\
2 & $80-89$ & 2 & 28,6 & Baik \\
3 & $70-79$ & 3 & 42,8 & Cukup \\
4 & $<70$ & 1 & 14,3 & Kurang \\
\hline & Jumlah & 7 & 100 & - \\
\hline
\end{tabular}

Sumber: Data Olahan Primer, 2017

Berdasarkan tabel 8 dapat diketahui bahwa guru yang menerapkan kompetensi pedagogik berdasarkan aspek perencanaan pembelajaran dengan kategori Sangat Baik hanya diperoleh satu orang guru (20\%). Pada umumnya guru memiliki kemampuan dalam merencanakan pembelajaran masuk dalam kategori cukup yang diperoleh 3 orang guru geografi $(42,8 \%)$.
Kompetensi pedagogik guru geografi ditinjau dari aspek pelaksanaan pembelajaran berdasarkan hasil observasi dan dokumentasi yang dilakukan di SMA Se-Kecamatan Hamparan Perak mendapatkan nilai rata-rata 64,03. Untuk lebih jelas dapat dilihat pada tabel 9 berikut.

Tabel 9. Penilaian Kompetensi Pedagogik Guru Geografi Berdasarkan Aspek Pelaksanaan Pembelajaran di SMA Se-Kecamatan Hamparan Perak Tahun Ajaran 2017/2018

\begin{tabular}{ccccccc}
\hline \multirow{2}{*}{ No } & \multirow{2}{*}{ Guru } & \multicolumn{3}{c}{ Penilaian } & \multirow{2}{*}{$\begin{array}{c}\text { Rata- } \\
\text { rata }\end{array}$} & Kategori \\
\cline { 3 - 5 } & & Pertemuan 1 & Pertemuan 2 & Pertemuan 3 & \\
\hline 1 & Guru 1 & 91,66 & 87,5 & 91,14 & 90,1 & Sangat Baik \\
2 & Guru 2 & 61,45 & 58,33 & 60,41 & 60,06 & Kurang \\
3 & Guru 3 & 50 & 59,37 & 49,47 & 52,94 & Kurang \\
4 & Guru 4 & 58,33 & 59,89 & 59,37 & 59,19 & Kurang \\
5 & Guru 5 & 71,35 & 71,35 & 70,31 & 71,00 & Cukup \\
6 & Guru 6 & 57,29 & 59,37 & 62,5 & 59,72 & Kurang \\
7 & Guru 7 & 54,16 & 56,25 & 55,20 & 55,20 & Kurang \\
\hline & Total Skor & 444,24 & 452,06 & 448,59 & 448,21 & \multirow{2}{*}{ Kurang } \\
\hline
\end{tabular}

Sumber: Data Olahan Primer, 2017

Berdasarkan tabel 9 dapat dilihat bahwa kemampuan guru dalam melaksanan pembelajaran tergolong dalam kategori Kurang dengan nilai rata-rata 64,03. Nilai pelaksanaan pembelajaran yang paling tinggi diperoleh guru SMA Negeri 1 Hamparan Perak dengan nilai rata-rata 90,1 tergolong dalam kategori Sangat Baik dan perolehan nilai pelaksanaan pembelajaran paling rendah diperoleh guru geografi SMA Swasta Swadaya dengan nilai rata-rata 52,94 tergolong dalam kategori Kurang.

Penilaian pelaksanaan pembelajaran juga dapat dilihat dari beberapa komponen penilaian pelaksanaan pembelajaran yang terdapat pada tabel 10. 
Tabel 10. Penilaian Rata-rata Pelaksanaan Pembelajaran Menurut Komponen Penilaian IPKG II

\begin{tabular}{cccccc}
\hline No & Guru & \multicolumn{3}{c}{ Penilaian } \\
\cline { 3 - 5 } & & KPd & KI & KP \\
\hline 1 & Guru 1 & & 3,80 & 3,84 & 2 \\
2 & Guru 2 & & 3,18 & 2,68 & 1 \\
3 & Guru 3 & & 2,09 & 2,16 & 1,53 \\
4 & Guru 4 & 2,71 & 2,47 & 1 \\
5 & Guru 5 & 3,09 & 3,04 & 1 \\
6 & Guru 6 & 2,71 & 2,53 & 1 \\
7 & Guru 7 & & 2,56 & 2,31 & 8,59 \\
\hline & & 20,14 & 19,03 & 1,22 \\
\hline
\end{tabular}

Sumber: Data Primer Olahan, 2017

Keterangan:

$\begin{array}{ll}\text { KPd } & \text { : Kegiatan Pendahuluan } \\ \text { KI } & \text { : Kegiatan Inti } \\ \text { KP } & \text { : Kegiatan Penutup }\end{array}$

Dari tabel 10 dapat dilihat bahwa nilai rata-rata yang diperoleh guru geografi di SMA Se-Kecamatan Hamparan Perak pada komponen kegiatan pendahuluan memperoleh nilai 2,87. Pada komponen ini masih terdapat guru yang belum menerapkan seluruh komponen yang terdapat dalam kegiatan pendahuluan seperti belum mengaitkan materi pembelajaran sekarang dengan pengalaman peserta didik, tidak memberikan pertanyaan yang menantang dan tidak menyampaikan rancangan kegiatan yang akan dilakukan siswa pada saat pembelajaran. Sedangkan nilai rata-rata komponen kegiatan inti memperoleh nilai 2,71 . Ppada komponen ini masih banyak guru yang belum melaksanakan kegiatan inti dengan maksimal seperti tidak mengaitkan materi dengan pengetahuan lain yang relevan yang sesuai dengan kehiduan nyata, penerapan saintific yang masih kurang, sumber dan media pembelajaran yang kurang bervariasi dan penilaian authentic yang belum terlaksana seluruhnya.

Sedangkan nilai komponen Kegiatan Pendahuluan merupakan nilai terendah dari kegiatan pendahuluan dan kegiatan inti yaitu memperoleh nilai rata-rata 1,22 . Hal ini dikarenakan pada kegiatan penutup guru geografi di SMA Se-Kecamatan Hamparan Perak banyak yang tidak membimbing peserta didik untuk merangkum pembelajaran yang sudah berlangsung, tidak merefleksi proses dan materi pembelajaran, tidak memberikan tes lisan maupun tulisan untuk mengukur kemampuan peserta didik serta tidak melaksanakan tindak lanjut dengan memberikan arahan kegiatan untuk kegiatan berikutnya.

Selanjutnya kategori analisis kompetensi pedagogik guru geografi dalam pelaksanaan pembelajaran dapat dilihat pada tabel 11 berikut.

Tabel 11. Kategori Kompetensi Pedagogik Guru Geografi Berdasarkan Aspek Pelaksanaan Pembelajaran di SMA Se Kecamatan Hamparan Perak Tahun Ajaran 2017/2018

\begin{tabular}{ccccc}
\hline No & Rentang Nilai & Jumlah Guru & Persen (\%) & $\begin{array}{c}\text { Kategori } \\
\text { Pelaksanaan } \\
\text { Pembelajaran }\end{array}$ \\
\hline 1 & $90-100$ & 1 & 14,3 & Sangat Baik \\
2 & $80-89$ & - & - & Baik \\
3 & $70-79$ & 1 & 14,3 & Cukup \\
4 & $<70$ & 5 & 71,4 & Kurang \\
\hline & 7 & 100 & - \\
\hline & Jumlah & & Sumber: Data Olahan Primer, 2017
\end{tabular}


Berdasarkan tabel 11 dapat dilihat bahwa hanya terdapat 1 orang guru geografi yang memperoleh kategori Sangat Baik (14,3\%) dalam melaksanakan pembelajaran. Selain itu tidak terdapat guru yang memperoleh nilai dengan kategori baik. Terdapat 1 orang guru yang memperolah nilai dengan kategori Cukup $(14,3 \%)$ dan pada umumnya guru geografi memperoleh nilai dengan kategori
Kurang yaitu sebanyak $71,4 \%$ dari 7 orang guru di SMA Se-Kecamatan Hamparan Perak.

Untuk mengetahui nilai akhir dari analisis kompetensi pedagogik guru geografi berdasarkan aspek Perencanaan Pelaksanaan Pembelajaran dan Pelaksanaan Pembelajaran maka diperlukan penggabungan nilai berdasarkan nilai yang terdapat pada IPKG I dan IPKC II. Untuk penjelasannya dapat dilihat pada tabel 12 .

Tabel 12. Nilai Akhir Analisis Kompetensi Pedagogik Guru Geografi Berdasarkan IPKC I dan IPKC II

\begin{tabular}{|c|c|c|c|c|}
\hline No & Nama Guru & IPKG I & IPKG II & Nilai Akhir \\
\hline 1 & Guru 1 & 96,33 & 90,1 & 93,21 \\
\hline 2 & Guru 2 & 84,71 & 60,06 & 72,38 \\
\hline 3 & Guru 3 & 59,44 & 52,94 & 56,19 \\
\hline 4 & Guru 4 & 74,71 & 59,19 & 66,95 \\
\hline 5 & Guru 5 & 89,16 & 71,00 & 80,08 \\
\hline 6 & Guru 6 & 76,66 & 59,72 & 68,19 \\
\hline 7 & Guru 7 & 76,33 & 55,20 & 65,76 \\
\hline & Jumlah & 554,06 & 448,21 & 501,12 \\
\hline & Rata-rata & 79,62 & 64,03 & 71,82 \\
\hline
\end{tabular}

Berdasarkan tabel 12 dapat dilihat bahwa analisis kompetensi pedagogik guru geografi di SMA Se-Kecamatan Hamparan Perak berdasarkan aspek Rencana Pelaksanaan Pembelajaran (RPP) termasuk dalam kategori Cukup dengan nilai rata 79,62. Berdasarkan aspek Pelaksanaan Pembelajaran termasuk dalam kategori Kurang dengan nilai rata-rata 64,03. Sedangkan berdasarkan nilai akhir penggabungan dari kedua aspek ini memperoleh nilai rata-rata tertinggi dalam penerapan kompetensi pedagogik guru geografi memperoleh nilai 93,21 dan nilai akhir rata-rata terendah memperoleh nilai 56,19 .

Maka berdasarkan hasil nilai akhir dari penilaian kompetensi pedagogik guru geografi berdasarkan aspek perencanaan pembelajaran dan pelaksanaan pembelajaran guru gegrafi di SMA Se-Kecamatan Hamparan Perak dikategorikan Cukp dengan nilai akhir adalah 71,82 .

\section{Kompetensi Pedagogik Guru Geografi Berdasarkan Aspek Perencanaan Pembelajaran di SMA Se-Kecamatan Hamparan Perak.}

Kompetensi pedagogik guru geografi berdasarkan aspek perencanaan pembelajaran di SMA Se-Kecamatan Hamparan Perak yang berjumlah 7 orang. Dalam Rencana
Pelaksanaan Pembelajaran (RPP) terdapat 9 komponen kemampuan guru seperti yang tercantum dalam IPKC I yaitu identitas mata pelajaran, perumusan indikator, perumusan tujuan pembelajaran, pemilihan materi ajar, pemilihan sumber belajar, pemilihan media ajar, metode pembelajaran, skenario pembelajaran, rancangan penilaian authentic.

Berdasarkan hasil penelitian yang dilakukan pada guru geografi di SMA SeKecamatan Hamparan Perak secara umum kompetensi pedagogik guru geografi dalam aspek perencanaan pembelajaran masih dalam kategori Cukup. Hal ini dikarenakan masih terdapat guru yang belum merancang rencana pembelajaran dengan baik seperti perumusan indikator belum sesuai dengan kompetensi dasar, kesesuaian dengan pendekatan scintific dan kesesuaian rancangan penilaian authentic. Selain itu terdapat nilai rencana pelaksanaan pembelajaran yang sangat rendah yaitu 59,44 sehingga nilai akhir rata-rata rencana pelaksanaan pembelajaran (RPP) menjadi rendah dengan kategori Cukup. Rendahnya nilai yang diperoleh guru geografi di dukung oleh tidak sesuainya lulusan akademik dengan mata pelajaran yang diampu, dimana dari dari 7 orang guru terdapat 3 orang guru yang bukan merupakan lulusan dari sarjana pendidikan geografi. 
Hal ini sejalan dengan nilai rata-rata yang diperoleh lbu Demirah Syahifa yang merupakan lulusan Pendidikan Bahasa Inggris yang memperoleh nilai 59,44 dengan kategori Kurang, Ibu Khairani merupakan lulusan Hukum Islam memperoleh nilai 74,71 dengan kategori Cukup, dan bapak HD Siregar yang merupakan lulusan SMEA memperoleh nilai 76,33 dengan kategori Cukup. Sedangkan 4 orang guru lainnya merupakan lulusan sarjana Pendidikan Geografi. Nilai tertinggi diperoleh Ibu Vivi Astuti yaitu 96,33 dengan kategori Sangat Baik, Ibu Marlita Berampu memperoleh nilai 89,16 dengan kategori Baik, Bapak Suparlan memperoleh nilai 84,71 dengan kategori Baik dan Bapak Nasip memperoleh nilai 76,66 dengan kategori Cukup. Dari nilai yang diperoleh 7 orang guru geografi membuktikan bahwa lulusan akademik sangat berpengaruh terhadap pelajaran yang diampu. Dimana guru yang merupakan lulusan akademik dari pendidikan georafi akan lebih baik dalam merancang rencanaan pembelajaran sesuai dengan aspekaspek yang terdapat di dalamnya dari pada guru yang bukan merupakan lulusan pendidikan geografi.

Maka nilai yang diperoleh seluruh guru geografi dalam aspek Rencana Pelaksanaan Pembelajaran (RPP) yang dirancang guru termasuk dalam kategori Cukup dengan perolehan nilai 79,62.

\section{Kompetensi Pedagogik Guru Geografi Berdasarkan Aspek Pelaksanaan Pembelajaran di SMA Se-Kecamatan Hamparan Perak}

Pelaksanaan pembelajaran yang dilakukan oleh guru geografi di SMA Se-Kecamatan Hamparan Perak termasuk dalam kategori Kurang dengan nilai rata-rata 64,03. Pada saat pembelajaran berlangsung guru belum sepenuhnya menerapkan Rancangan Pelaksanaan Pembelajaran (RPP) yang telah dirancang oleh masing-masing guru dan belum sesuai dengan 9 komponen dalam penilaian IPKC II yaitu: apersepsi dan motivasi, penyampaian kompetensi dan rencana kegiatan, penguasaan materi pembelajaran, penerapan strategi pembelajaran yang mendidik, penerapan pendekatan scientific, pemanfaatan sumber belajar/media dalam pembelajaran, pelaksanaan penilaian authentic, pelibatan peserta didik dalam pembelajaran, penggunaan bahasa yang benar dan tepat dalam pembelajaran serta menutup pembelajaran.

Dalam proses pembelajaran berlangsung pada kegiatan pendahuluan guru sudah mampu dalam memberikan apersepsi dan motivasi kepada peserta didik. Akan tetapi pada saat kegiatan inti masih banyak terdapat guru yang kurang dalam menguasai kelas, mengalami kesulitan dalam menghadapi berbagai karakteristik siswa dan sulit dalam menumbuhkan partisipasi peserta didik agar dapat aktif dalam kegiatan pembelajaran. Selain itu guru mengalami kesulitan dalam membawakan materi pelajaran, hal ini dikarenakan terdapat beberapa guru yang bukan merupakan lulusan pendidikan geografi, tidak begitu memahami mengenai materi-materi geografi sehingga hal tersebut berdampak pada buruk nya kualitas pelaksanaan pembelajaran dan rendahnya nilai pelaksanaan pembelajaran guru di dalam kelas.

Penilaian IPKC II pada pelaksanaan pembelajaran dilihat pada saat guru mengajar di kelas. Sesuai tabel 37 dapat dilihat bahwa nilai tertinggi diperoleh lbu Vivi Astuti yaitu 90,1 dengan kategori Sangat Baik sedangkan nilai terendah diperoleh Ibu Demirah Syahifa yaitu 52,94 dengan kategori Kurang. Maka nilai rata-rata yang diperoleh guru geografi di SMA Se-Kecamatan Hamparan Perak dalam aspek pelaksanaan pembelajaran memperoleh nilai 64,03 dengan kategori Kurang.

Dari hasil penilaian Rancangan Pelaksanaan Pembelajaran dan Pelaksanaan Proses Pembelajaran menunjukkan bahwa Analisis Kompetensi Pedagogik Guru Geografi di SMA Se-Kecamatan Hamparan Perak masih dalam kategori Cukup dengan nilai akhir yang merupakan nilai rata-rata dari seluruh guru geografi yang berjumlah 7 orang yaitu memperoleh nilai 71,82 .

Hasil penelitian ini sejalan dengan penelitian Johan (2015) yang menunjukan bahwa kompetensi pedagogik yang di miliki guru geografi adalah cukup dengan rata - rata nilai terakhir adalah 76,60 yang dapat di nilai dari aspek perencanaan pembelajaran dan aspek pelaksanaan pembelajaran adalah masih rendah dengan kategori cukup. Dimana kompetensi pedagogik guru geografi berdasarkan aspek perencanaan pembelajaran yang dibuat oleh guru adalah kategori cukup $(76,00)$, serta pada aspek pelaksanaan 
pembelajaran yang di buat oleh guru juga dalam kategori cukup $(78,00)$.

\section{KESIMPULAN}

Berdasarkan hasil penelitian dan pembahasan yang telah diuraikan, maka kesimpulan yang dapat diambil menunjukkan bahwa analisis kompetensi pedagogik guru geografi berdasarkan aspek Rencana Pelaksanaan Pembelajaran (RPP) masih dalam kategori Cukup $(79,62)$. Hal ini dikarenakan terdapat nilai rencana pelaksanaan pembelajaran yang sangat rendah yaitu 59,44 sehingga nilai akhir rata-rata rencana pelaksanaan pembelajaran (RPP) menjadi rendah dengan kategori Cukup. Akan tetapi jika dilihat dari nilai rata-rata rencana pelaksanaan pembelajaran yang diperoleh masing-masing guru geografi, nilai yang diperoleh sudah tergolong dalam kategori Cukup, Baik dan Sangat Baik. Dan dilihat dari aspek pelaksanaan pembelajaran guru geografi masih dalam kategori Kurang (64,03). Hal ini dikarenakan sebagian besar nilai rata-rata yang diperoleh guru geografi dalam pelaksanaan pembelajaran masih rendah. Hanya terdapat satu orang guru yang memperoleh nilai tinggi dengan kategori Sangat Baik. Sehingga nilai akhir rata-rata yang diperoleh guru dalam aspek pelaksanaan pembelajaran tergolong dalam kategori Kurang.

Secara umum Analisis Kompetensi Pedagogik Guru Geografi di SMA SeKecamatan Hamparan Perak Tahun Ajaran 2017/2018 tergolong dalam karegori Cukup dengan nilai akhir yang merupakan nilai ratarata dari seluruh guru geografi yang berjumlah 7 orang yaitu 71,82 .

\section{DAFTAR PUSTAKA}

Arikunto, S. 2013. Prosedur Penelitian Suatu Pendekatan Praktik. Jakarta: Rineka Cipta. Hamalik, Oemar. 2009. Pendidikan Guru Berdasarkan Pendekatan Kompetensi. Jakarta: Bumi Aksara.

Irwantoro, Nur dan Suryana, Yusuf. 2016. Kompetensi Pedagogik: Genta Group Production.

Johan. 2015. Analisis Kompetensi Pedagogik Guru Geografi di SMA Negeri Se- Kota Binjai. Skripsi. Fakultas Ilmu Sosial Universitas Negeri Medan.
Kunandar. 2014. Guru Profesional. Jakarta: PT Raja Grafindo Persada.

Permendikbud Nomor 16 Tahun 2007 tentang Standar Kualifikasi Akademik dan Kompetensi Guru.

Pendidikan Geografi Fakultas Ilmu Sosial Universitas Negeri Medan.

Undang-undang RI Nomor 14 Tahun 2005, tentang Guru dan Dosen, Pasal 10 ayat 1. 
available at http://jurnal.unimed.ac.id/2012/index.php/tgeo

Jurnal Tunas Geografi

e-ISSN: 2622-9528 p-ISSN: 2301-606X

Vol 07 No. $01-2018$ 